\title{
発現行動型アーキテクチャによるアームロボットの制御
}

\author{
中 内 靖* 西田 洋一郎* 森 泰 親*

\section{The Control of Arm Robot by Using Emergent Behavior Based Architecture}

Yasushi Nakauchi*, Youichiro Nishida* and Yasuchika Mori*

\begin{abstract}
In order to utilize robots in the service fields, such as in offices and in hospitals, the robots should equip the functions for coexisting with human. In this paper, we propose EBBA (Emergent Behavior Based Architecture) for that purpose. EBBA is constructed by behavior modules. And each module can act concurrently by referring inputs from sensors, its object states and its internal states. And the emergent behavior of the system is defined by a certain set of the object states. Therefore, a planner (one of the behavior modules) can control the emergent behavior of the system by reffering and by changing the other modules' object states and internal states. We have implemented a robot hand system by using EBBA. We also shows that the system can perform tasks efficiently by selecting emergent behaviors as the experimental results.
\end{abstract}

Key Words: Arm Robots, Behavior-based AI, Adaptive Behavior, Obstacle Avoidance, Tactile Skills

\section{1.はじめに}

ロボットはこれまで主に産業分野で実用化され，その高い利 用価值が認められてきた。また近年，自律移動ロボットを産業 用に限らず，例えば医療における看護ロボットや床清掃ロボッ トなど,より広い分野で利用したいという要求が高まってきて いる，病院での看護や，清掃，オフィスでのメールの配送など のサービスを行うロボットは, 人間の存在する環境で, 人間や 他のロボットと共同で作業を行うことがある．このような協調 作業を行うロボットは，人間と作業環境を共有するため，その 作業を行う環境に様々な変化がある．そのためロボットは，あ らかじめ障害物の位置等を知ることはできない。このように， 人間との協調を考えた汎用サービスロボットは，様々な障害物 を回避しつつ，作業を続けられなくてはならない. したがって 人間共存型ロボットには，環境に存在する障害物を確実に検知 できることが要求される．また人間共存型ロボットは，このよ うな様々な渨境に適応しながら，目的とする動作を実行できな ければならない.ロボットをこのような状況に適応させるため には，与えられたタスクを遂行できるまで，考えうる複数通り の手段を講じさせるなど, システムが失敗に陥らないような処 理構造にしなければならない.

そこで本研究では，人間共存型ロボットに必要となる環境へ の適応能力について検討し，その機能を実現するロボットの

原稿受付 1996 年 4 月 22 日

*防街大学校

* National Defense Academy
制御方法として発現行動型アーキテクチャ (EBBA: Emergent Behavior Based Architecture) を提案する. 我々の研究室で は現在, 人間共存型ロボットを目指して, 双腕型自律移動ロ ボットWM (Work Mate) [2] を開発中である (Fig. 1 参照). WM は 2 輪駆動型の移動ロボットベースの上に, 表面全面に 接触センサが取り付けられた 6 軸型アームロボット 2 台と 3 自 由度のステレオビジョン・ヘッドシステムが搭載された構成と なっている.我々は WM をオフィスなどの整備されていない 環境において利用することを考えており, 例えば人がコーヒー を入れるように命令すると, 必要なコーヒーの缶やコップなど をビジョンにより探索し，入れたコーヒーを命令した人間のオ フィスまで運ばせるアプリケーションを考えている．このよう な環境で WM が, コップを取ろうと腕を伸ばすと, 周囲の人 間または他の午に腕が当たることが予想される，人間に対して は安全であり，また他の障害物に関しては回避するなどして， 与えられたタスクを自律的に遂行できる必要がある。

上記に述べた動作をWM を用いて実現するためにはまず， WM の個々の構成要素が人間との共存環境において適応して 動作できるように作成し，その後に統合化を図る必要があると 考える．そこで本研究では，WM のアーム部にEBBAを適用 し, 接触センサの情報のみを利用して, 環境に適応したアーム ロボットを開発する。また実験により，EBBAの有効性を検証 する.

\section{2. 人間共存型ロボット}

人間と共存するロボットには，環境ならびに人間の知覚，人 


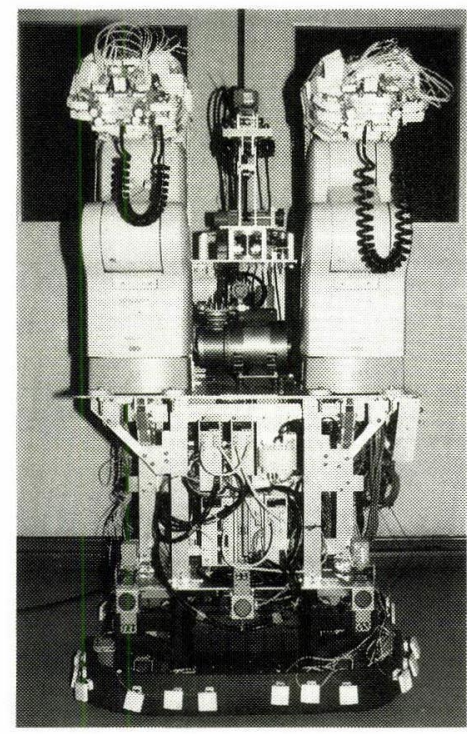

Fig. 1 The out look of WM (Work Mate)

間の精神的態度（信念, 意思, 感情など) の理解, これらの知 覚, 理解をもとにした問題解決能力, 言語, ジエスチャ, 行動 などによる内部状態の表出能力などが必要と考えられる [1].こ れらの能力を実現すべく，様々な研究がなされているが，精神 的な態度の理解などの高度なインタラクションを図る以前に, ロボットは機械システムとして, 以下に述べる基本的な機能を 満足している必要があると考えられる。

まず人間共存型ロボットの利用環境では, 人間とロボットが 互いの作業環境を共有するため, 人間とロボットが物理的に衝 突する恐れがある。そのため, ロボットは差し出した腕が人間 と接触した場合には腕を引くなどして，人間に危害を及ほさな いようにする必要がある。また, 人間がロボットの作業環境に 間接的に影響する場合が考えられる。例えば，ロボットの作業 空間のなかに, 人間によって障害物を置かれたり，それまで存 在していた物を取り除かれたりする場合がある。また，人間の 腕や体が直接障害物となる場合も考えられる。一般に障害物は, 机の上のコップや計算機など, 空間を占有し続ける静的な障害 物と, 人間や他のロボットのように一時的に占有する動的なも のの 2 種類に分けられる. 人間共存型ロボットの利用環境が動 的であるのは，このような障害物が多く存在するからである. したがって, 人間共存型ロボットはこのような障害物（静的, 動 的）を回避して動作できなくてはならない。さらに，人間と共 存して動作するには，与えられた夕スクを遂行できずに，機能 が停止してしまうようなことでは使いものにならない.ある夕 スクを遂行するために必要な手法を複数用意してシステムに圥 長性をもたせ, フォールトトレラントなシステムにするだけで なく，与えられた夕スクを遂行できるまで，考えうる複数通り の手法を用いて再試行するなどし, システムとしては動作不能 状態に陥ることのないようにしなげればならない，以上に述べ た, 人間共存型ロボットの具備すべき基本的な要件は Table 1 のようにまとめられる.

これらの要件のうちb）ならびに c) は一般のロボットにも 当てはまるが, これらの要件を満足しているシステムは現状で
Table 1 Basic functions for human coexistent robots

\begin{tabular}{l} 
a） 人に危害を加えないこと \\
b) 障害物（静的，動的）に対応できること \\
c) システムがフェイル (失敗) しないこと \\
\hline
\end{tabular}

は見当たらない，一般のロボットの使用環境では運転者が監視 しているため, これらの要件が満足されていなくても, 人間な らびに障害物が入り込まないように柵を張りめぐらせたり, 運 転者が障害物を除去したり, 再起動によりフェイルリカバリす るなどし, 運用されているのが現状である. ところが人間共存 型ロボットでは, 整備されていない環境において人間の監視な しに動作し続けることこそが重要であると考えられる．そこで 本研究では, これら三つの基本的な要件を満足するシステムの 構築を目的とする.

D. Vischer は, 人間と共存するロボットの一例として, 食器 を仕分けるロボットを開発した[3]. このシステムでは, CCD カメラを用いて周囲の環境の情報を入力しており, ロボットの 作業環境内に人間が入ってくると, ロボットの動作速度を遅く する. またロボットの暴走を防止するために, 加速度検知器を 用いてロボットの位置決めを監視しており, 異常時にはただち に非常停止するようになっている。しかしこのシステムでは, 最終的には人間がロボットを避けなければならず, 人間とロボッ トの作業空間は排他的なものとなっている. 人間とロボットが 共存するためには，お互いが作業を行う空間を共有し，お互い が避け合える必要がある。

ロボットにコップを掴ませるとき,コップ本体を避けて、コッ プ両端にロボットの指が掛かるように位置決めする必要があ る、このときコップ本体は静的な障害物と見なすことができる. S.A. Stansfield [4] らはロボットにコップを把持させるために, CCD カメラから得られた画像情報を用いて，ロボットにコッ プを把持するためにふさわしい指の形をあらかじめ形成させた 後に、コップに接触しないようにコップの両端に指を挿入する システムを開発している。しかしながら, 画像処理のコストが 高いため, 画像情報の質をコップを認識できる必要最低限に落 としている.ここで, コップ以外の障害物や人間が作業環境に 存在した場合, それらを画像処理によって回避することはでき ない.

一方, P.K. Allen [5] らは二次元平面上を移動する対象物を $\mathrm{CCD}$ カメラで捉えて観察し, その動作を予測しながら対象物 を把持するシステムを開発している。移動物体の動作を予測す るために, 画像のオプティカルフローの計算には専用のパイプ ライン計算機を用いている。しかしながら，このシステムを用 いて動的な障害物回避を行わせるためには, 任意の背景のなか を三次元的に移動する対象物の動作を抽出し, 移動先を予測し なくてはならない.また, 動的障害物と腕との接触を避けるた めには両方ともが動いているため, 画像によって障害物のみを 抽出することは非常に困難である.

このように, 静的ならびに動的な障害物を認識するためには, 画像処理を用いているのでは計算量が大きいため, 確実に回避 することは困難である，さらら現状では任意の位置にある任意 の数の静的または動的な障害物の位置ならびに移動方向を計測 
することも非常に困難である†。一方，接触センサを用いた場 合，環境を確実に検知することは可能であるが，接触してはじ めて障害物回避を行うことになってしまう。そのため,これら を併用し接触センサを用いることにより，障害物に接触はする ものの, 確実に障害物を回避できるシステムを構築し，そのう えで非接触センサを用いた回避システムを構築することが望ま しいと考えられる，そこで本研究ではまず，接触センサを利用 することにより，静的ならびに動的障害物を確実に検知し，こ れらを回避できるシステムを構築することとする.

センサベースの行動モジュールを組み合わせてシステムを 構築する設計手法として, サブサンプション・アーキテクチャ (SSA: Subsumption Architecture) [6] [7] が提案されている. SSA はセンサーベースの行動モジュールを階層構造にすること により,システムに圥長性を持たせ，様々な状況においてフェ イルしにくいシステム構成となっている.

我々はこれまでに, SSAを用いて動的環境に適応できるロ ボットハンドシステムを構䇠してきた [8] [9].これらのシステム では障害物を接触センサにより検知し，上方または下方から障 害物を回避できるように，回避の方向ごとに行動モジュールを 用意してシステムにて長性を持たせた。 そして，プランナが状 況に応じて適当な行動モジュールを選択することにより様々な 状況に適応していた。ところが，障害物回避の方法には，この ほかにも障害物を迁回しながら回避する場合や押し退けながら 回避する場合が考えられる.SSA を用いてこのような回避行動 を実現しようとすると, 用意しなくてはならない行動モジュー ルの数が膨大なものとなってしまう.

そこで本研究では行動モジュールの数の爆発を抑えるととも に, 圥長な行動を保持することのできるアーキテクチャとして EBBA を提案する. 以下にEBBA について説明する.

\section{EBBA（発現行動型アーキテクチャ）}

\section{1 発現行動}

Table 2 に示すように二つの行動モジュール A と B を考え る. 行動モジュール A はロボットハンドに障害物が接触する と起動され，反射行動的に腕を少し移動する，一方，行動モ ジュール B は行動モジュール A に引き続いて起動され, 障害物 を回り込むように腕を大きく移動する．両モジュールとも，パ ラメータとして移動する方向を持っており, パラメータにより 移動方向が決定される。

例えば腕をある方向に移動させているときに腕が障害物に接 触すると，まず行動モジュール A が起動され，いったん停止し， 来た経路の方向に少し進む.さらに，行動モジュール B で接触 した方向に対して 90 度偏向した方向に少し進むと, 障害物を 迁回しながら回避する行動となる.ここで, 行動モジュール A, $\mathrm{B}$ のパラメータを少し変更すると, 行動モジュール A で, 接触 したら停止し, 進行方向に少し進み, 行動モジュール B で接触 した方向に少し進ませることができる。この行動は障害物を押 し退けながら回避する行動になる.

このように各行動モジュールで利用されるパラメータを少し 変更するだけで, 行動モジュールの組み合わせとして発現する 行動 (EB: Emergent Behavior) ${ }^{\dagger \dagger}$ が変化する.そしてプラン
Table 2 Emergent behaviors caused by the different interaction with environments

\begin{tabular}{|c|c|c|}
\hline 行動モジュール & 目的行動 1 & 目的行動 2 \\
\hline A & $\begin{array}{l}\text { 単害物に接触したら停 } \\
\text { 止し，来た経路の方向 } \\
\text { に少し進む. }\end{array}$ & $\begin{array}{l}\text { 障害物に接触したら停 } \\
\text { 止し, 進行方向に少し } \\
\text { 進む. }\end{array}$ \\
\hline B & $\begin{array}{l}\text { 障害物と接触した方向 } \\
\text { に対して } 90 \text { 度偏向した } \\
\text { 方向に少し進む. }\end{array}$ & $\begin{array}{l}\text { 障害物と接触した方向 } \\
\text { に少し進む. }\end{array}$ \\
\hline 発現する行動 & 障害物回避行動 & 障害物排除行動 \\
\hline
\end{tabular}

Table 3 Fundamental functions of EBBA

i） センサベースの処理構造を持つこと

ii）動作を小さな行動モジュールの組み合わせで表現できること

iii）目的を達成するための手段を複数通り持つことができること

iv）プランナが行動モジュールを制御できること

ナが単位行動モジュールをパラメータを書き換えることにより, システム全体として発現する行動を制御できると考えられる. このような構造にすることにより, プランナはパスプランニン グを行うだけでなく，一つのサブプラン実行中に障害物回避を 行わなくてはならない場合, 下位の行動モジュールの実行状態 をモニタし, 障害物回避のために発現する行動を切り替えるこ とができる.

我々は, Table 1 に示した要件を満足するために, 以下の方 針に従って EBBA を設計した。 まず，a）人に危害を加えない ためには，七ンサからの入力情報を利用した確実な障害物およ び人間の感知を図る必要がある.このためシステムは, i）七ン サ情報を用いたセンサベースの処理構造を持つ必要がある。 た，b）障害物（静的，動的）に対応するためには，動的に変 化する環境に機敏に対応できるリアルタイム性をもった構造が 必要である．そこで, ii) 様々な動作を並行実行可能な小さな 行動モジュールとして実現する. そして, c) システムがフェイ ル（失敗）しないためには，iii）与えられたタスクを遂行する ために，考えうる幾通りもの手段を持つ必要がある．さらに， iv）これら複数の手段を状況に応じながら切り替えることによ り，タスク達成を目指した行動（以下, 目的行動とよふ）を行 えるプランナの機能が必要である. 以上に述べた, EBBAの特 徵を Table 3 にまとめる。

\subsection{EBBA の模成}

EBBA は，Fig. 2 に示すように，センサからの入力に加え， いくつかの内部状態（Internal States）ならびに一つの目的状

\footnotetext{
†近接センサ（超音波センサならびにフォトセンサなど）の利用も考え られるが，画像処理と同様に，任意の形状の障害物や任意の大きさの 障害物を検知することは困難であると考えられる。

${ }^{\dagger \dagger}$ Emergent（創発）とは一般に，環境および多数の行動モジュール（エー ジェント）の相互作用により，新たな機能や性質が害現される過程のこ とを意味する．上記の例ならびに EBBA では，複数の行動モジュール の組み合わせ（相互作用）により，新たに意味をもった行動が生成は されるが, これらの組み合わせはあらかじめ用意されているものを選 択するという手法をとっているため, 広義の Emergent Behavior と 見なすことができる.
} 


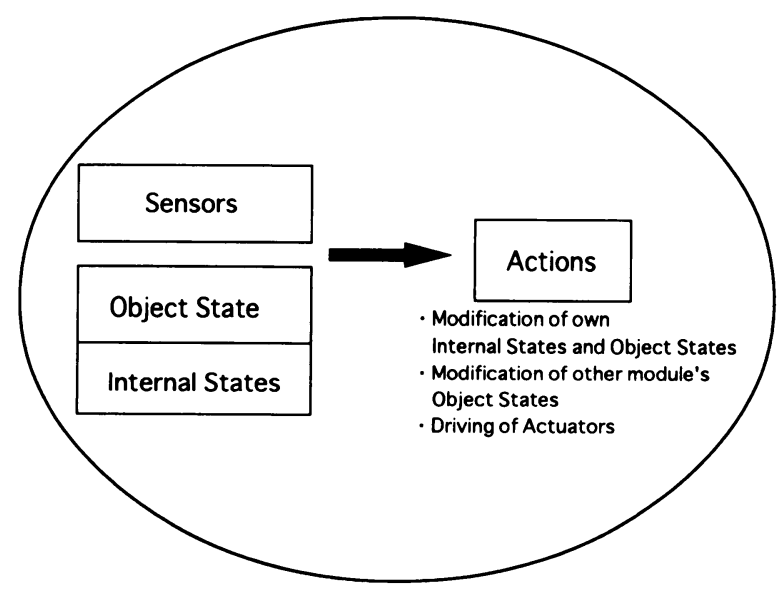

Fig. 2 A behavior module of EBBA

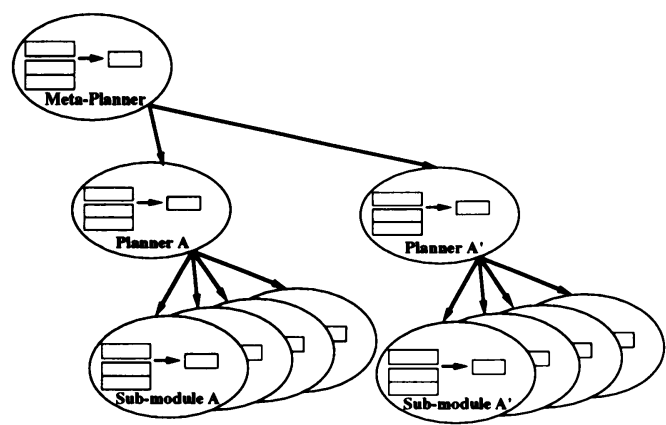

Fig. 3 System control architecture based on EBBA

態（Object States）をメモリとして持つ, 並行実行可能な行 動モジュールから構成される．各行動モジュールはその行動と して,アクチュエータの駆動ならびに他の行動モジュールの内 部状態㧍よび目的状態の操作を行うことができる．このような 構造にすることにより，必要な目的行動を実現できるとともに， これをプランナ等が容易に制御できるようになる，内部状態は， 他の行動モジュールから参照可能なメモリで，書き換えは自分 で行う. 目的状態は，ほかからも書き込み可能なメモリで，自 分でも書き換えることができる.

Fig. 3 に, EBBA における一般的な制御システムの構成を 示す. EBBAを利用したシステム設計ではまず，低レベルの 行動モジュールとして, エンコーダを入力とするモータの駆動 ルーチン，接触センサからの入力により起動される反射的行動 群, CCD カメラから得られた画像を用いた各種画像処理ルー チンなどが用意される，さらに，七ンサ入力から直接は起動さ れないが，上述した行動モジュール群の内部状態を参照するこ とによって起動される行動モジュールとして，反射行動を行っ た後に起動される行動モジュール群, ならびに画像処理などで 得られた抽象化された情報をもとに起動される行動モジュール 群などが用意される。 そして、これら行動モジュールを制御す るプランナが用意される。

EBBAではプランナも行動モジュールの一つとして実現され る.プランナは，一般の単位行動モジュールのセンサ入力にあ たる部分が, 支配下の単位行動モジュールの内部状態ならびに
目的状態に接続されているだけである．プランナはこの内部状 態と目的状態をモニタすることにより，下位モジュールの行動 を監視することができる．またプランナは，下位モジュールの 内部状態ならびに目的状態を書き換えることにより，所望の目 的行動を実現する。

このように，外界とインタラクションを行う下位モジュール の状態を基準に, 支配下の単位行動モジュールの行動を制御す るため, プランナも間接的にセンサベースに処理を行っている ことになる．また, EBBAではプランナを制御するさらに上位 のメタプランナを構筑することも可能である．プランナ自身も Fig. 2 に示寸構造となっており，内部状態ならびに目的状態を 持っている. したがって,メタプランナは支配下のプランナの 内部状態と目的状態を自分のセンサ入力に接続すればよい。こ のようにEBBA ではロボットの腕，脚，眼それぞれにプランナ を設け，それらを統合するメタプランナを構筑するなど，より 複雑なシステムの構成にも柔軟に対応できる構造となっている.

Fig. 2 で示した単位行動モジュールはセンサ入力に対して行 動を起こす点でSSA と似ているが，EBBAでは目的状態を明 示的に持ち、これらを書き換えることによって発現する行動を 制御可能としている. EBBAでは，これを単位行動モジュール としてシステムを組み，最終的に必要な行動目的表現を決定す る、この組み合わせ方は単純である。どの行動モジュールの内 部状態を参照したいか，どの行動モジュールの目的状態を書き 換えたいかを決めるだけである．また，これらが競合する可能 性がある場合は，優先順位を付けることができる．そうするこ とで，優先順位の高い行動を発現させることができる．

\section{4. システム構成}

\subsection{EBBA に基づくシステム榑成}

本研究では，障害物を避けて対象物を把持することのでき るアームロボットシステムを，EBBAに基づいて構築する。 Fig. 4 に EBBA による層構造をもった本研究の制御システム を示す．また，各行動モジュールが取り得る目的状態の一筧を Table 4 に示す. Fig. 4 の矢印は内部状態ならびに目的状態の 読み出し/書き込み線である。また， $\mathrm{s}$ と夆かれた丸への矢印は 優先順位付きの信号線を表しており，矢印付きで入る信号が他 の入力信号を抑制（subsume）することを示している.

図中，下位レベルには，システムがエラーを起こさないよう に最低限達成されなければならない行動を配置する，また上位 レベルには，最終的な目的を達成するために必要な，より高度 な行動を配置し、下位のレベルを参照しながら動作させる，各 行動モジュールは，各 level として表現されている．以下に各 level の行動について説明する.

level 0 [Move] では, サーボセンサからの情報をもとに, アー ム各関節の曲げ角を制御する。ここでは，目的状態として直線 移動または関節移動などの動作のパターンを持つ.

level 1 [Range Check] では, ロボットの各関節が可動範囲 内のであることを確認する．各関節の曲げ角をエンコータから 入力し，その状態を監視する. 目的状態は可動範囲内の確認で ある。

level 2 [Reflective Avoidance] では, 接触センサからの入力 


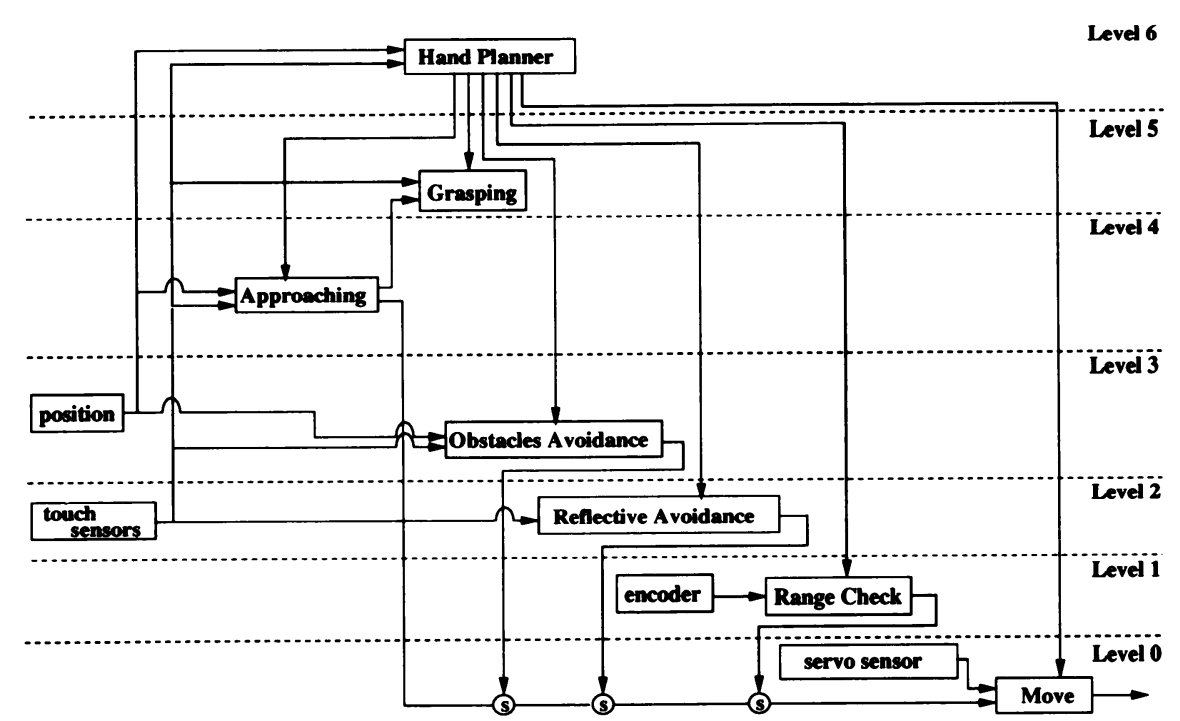

Fig. 4 Control system of arm robot based on EBBA

Table 4 Object states of each behavior module

\begin{tabular}{|c|c|c|}
\hline level & 行動モジュール & 目的状態 \\
\hline $\mathbf{0}$ & Move & $\begin{array}{l}\text { 直線移動 } \\
\text { 関節移動 } \\
\text { ハンド姿勢保持移動 } \\
\text { ハンド姿繁変更 }\end{array}$ \\
\hline 1 & Range Check & 可動範囲内確認 \\
\hline 2 & Reflective Avoidance & $\begin{array}{l}\text { 接触停止引き返し移動 } \\
\text { 接触停止引き続き移動 } \\
\text { 接触停止 }\end{array}$ \\
\hline 3 & Obstacles Avoidance & $\begin{array}{l}\text { 障害物迁回移動 } \\
\text { 障害物接近移動 }\end{array}$ \\
\hline 4 & Approaching & $\begin{array}{l}\text { 目的位置 } \\
\text { アプローチ方向 }\end{array}$ \\
\hline 5 & Grasping & $\begin{array}{l}\text { ハンド開 } \\
\text { ハンド閉 }\end{array}$ \\
\hline 6 & Hand Planner & $\begin{array}{l}\text { 目的位鲳 } \\
\text { ハンド状態 }\end{array}$ \\
\hline
\end{tabular}

をもとに障害物に接触した場合に衝突を回避する，目的状態は 接触停止後の動作を規定し, 動作しない状態も取り得る。また， level 0 の目的状態を書き換えることにより, 衝突回避時の口 ボットの移動モードを変更する.

level 3 [Obstacles Avoidance] では，接触センサとアームの ポジション情報ならびに目的状態をもとに，障害物接触後に迁 回または接近する。またアーム動作時に, level 0 の目的状態を 青き換えることにより，移動モードを変更する．

level 4 [Approaching] では，センサは接触センサとアームの ポジションの情報をもとに，目的位置に接近する方向を制御す る、目的状態はアプローチ方向またはサブゴールである.アプ ローチの方向が設定されると，その方向に向かうように level 0 の目的状態を書き換える。

level 5 [Grasping] では，目的状態ならびに接触センサの情 報をもとに，ハンドを開閉する。 level 6 [Hand Planner] では, 所望のタスクを達成するため に，サブゴールからなるプランを生成する．そして，下位モ ジュールの目的状態を書き換えることによりシステム全体とし て発現する行動を制御しながらサブコールを一つずつ達成する. 目的状態は目的位贯（与えられたタスク）であり, センサ入力 としてハンド先端のポジションならびに支配下の行動モジュー ルの内部状態を用いる．また，内部状態として支配下のすべて の行動モジュールの目的状態が接続されている.

\section{2 接触情報を用いたロボットの発現行预}

人間が腕を伸ばして物をとろうとして肘などが障害物に接触 したとき，一般に Table 5 に示す 3 種類の方法をとると考え られる.そこで本研究では Fig. 4 に示した EBBA の構成を利 用し、これら 3 種類の障害物回避を実現する。

3 種類の発現行動はそれぞれ, level 2 ならびに level 3 の目 的状態を Table 6 に示すように変更することにより実現され る. 完全回避発現行動では障害物に接触すると, まず level 2 に よりいったん動作を停止し，少し引き返す．さらにlevel 3 によ りアプローチする方向を変更し, 障害物を回り込みながら目的 位置にハンド先端を移動させる。

巻き付き回避発現行動では障害物に接触すると,まず level 2 により，障害物に接触した状態で停止する．ここで, level 0 が 関節移動であることから，接触した部分より先に位置する関節 のみを利用して目的位置へとハンド先端が移動する.このよう に，障害物に接触した部分をそのままに，巻き付くように目的 位置へ腕を伸ばす.

押し退け回避発現行動では障害物に接触すると，まず level 2 により障害物に接触するといったん停止し，さらに少し押し接 触した位置まで戻る動作を行う。この動作後に接触センサが反 応しない場合，障害物を押せたことが分かる．押せたと判断し た場合, level 2 が level 3 の目的状態を障害物接近移動に書き 換えることにより，ハンドは障害物の存在する方向へ移動する. このように一連の行動が実行されることにより全体として，障 害物を押し退けながら目的位置にハンドを位贯させる行動が発 
Table 5 The methods for obstacles avoidance

\begin{tabular}{|l|l|}
\hline $\begin{array}{c}\text { 回避モード } \\
\text { (発現行動) }\end{array}$ & 回避方法 \\
\hline \hline 完全回避 & 接触状態を解除して目的位置へ向かう \\
\hline 巻き付き回避 & 接触した障害物に巻き付いて目的位置へ向かう \\
\hline 押し退け回避 & 接触した障害物を押し退けて目的位置に向かう \\
\hline
\end{tabular}

Table 6 The variation of emergent behavior by the set of object states

\begin{tabular}{|c|c|c|c|}
\hline \multirow{2}{*}{$\begin{array}{l}\text { 回避モート } \\
\text { (発現行動) }\end{array}$} & \multicolumn{3}{|c|}{ 目的状態 } \\
\hline & level 0 & level 2 & level 3 \\
\hline 完全回避 & 直線移動 & 接触停止引き返し移動 & 障害物迁回移動 \\
\hline 巻き付き回避 & 関節移動 & 接触停止 & 障害物迁回移動 \\
\hline 押し退け回避 & 直線移動 & 接触停止引き続き移動 & 障害物接近移動 \\
\hline
\end{tabular}

現する.

プランナはこれらの発現行動を制御するために，各レベルの 目的状態を書き換えるだけでよい．例えば，完全回避を行って いてなかなか目的位置に近付けない状態を，プランナは下位モ ジュールの内部状態をモニタすることにより検知することがで きる.このような場合，プランナが発現行動を切り替えること により，効率よくタスクを実行することが可能である．また， 単純な発現行動の綝り返しでは,リミットサイクルに陥る場合 も考えられる.プランナはハンド先端の移動の履歷を保持する ことによりこれを検知し，アプローチの方向を大きく変更する ことにより回避することも可能である.

本研究では, プランナは指定された位置に順次ハンド先端を 位置決めするように, Approaching 行動モジュールに位置情報 を指定するとともに, 初期状態では回避モードを完全回避モー ドにし，障害物接触時に同じ回避モードが 3 回繰り返すごとに， それまでの回避行動の履歷をもとに他の回避モードを選択して 切り替える, 単純なものとして設計した。

\section{5. システムの実装}

Fig. 5 に本システムのハードウェア構成を示す．双腕型ロ ボットの腕として, 6 軸型ロボットアーム三菱電機製 RV-E2 を 2 台利用した. ハンドにはハメック製エアー駆動型ハンド（オー プン/クローズ 2 チャンネル）を用いた。またロボットアーム の表面には接触センサとして, ウレタンスポンジを使って接触 面積を広げたマイクロスイッチを 1 台あたり 32 個取り付けた.

ホストコンピュータには，AVME-130MPU モジュールに リアルタイム OS VxWorks を搭載して用いた。また，インタ フェースにAVME-350 シリアル回線増設ボードと AVME-342 パラレル回線増設ボードを使用した。ささらに，ソフトウェア開 発用にSPARC Classic を利用した。

EBBA の各行動モジュールは $\mathrm{C}$ 言語の関数として記述され， 行動の追加に際しては新たに関数を付け加えてることにより， 行動モジュールの層構造を実現した。これらの関数は並行実行 されるVxWorksのタスクとして実装した，さらにVxWorks のリアルタイムスケジューリング機能を利用することにより， センサ情報のサンプリングタイムが一定時間内になるようにし，

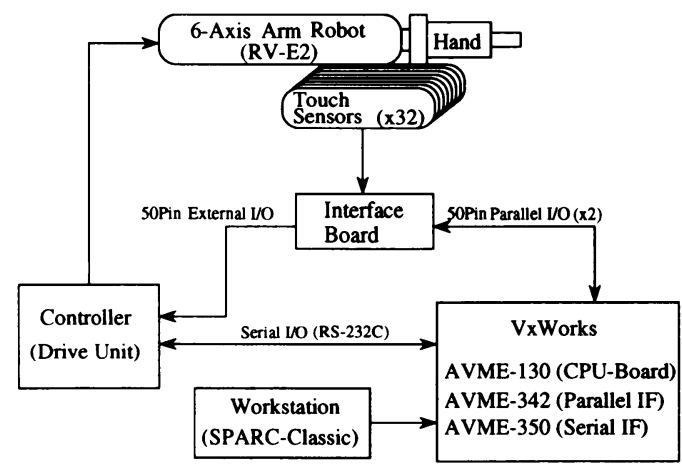

Fig. 5 Hardware structure of robot hand system

障害物との接触を確実に検知できるようにした。

\section{6. 実験}

本システムの有効性を示すために，以下に示す 5 種類の状況 を設定し，実験を行った．実験 1〜3では Table 6 に示した 3 種類の発現行動の有効性を確かめるために, プランナが終始同 一の発現行動を設定するようにして実験を行った．実験 5 では 人に危害を加えないことを確かめるために, 完全回避発現行動 のみが選択されるようにして実験を行った．またすべての実験 において, ハンド先端の初期位置, サブゴール, 目的位置はそ れぞれ，アームロボットの可動範囲内の三次元空間上の任意の 点を指定した．なお，障害物に関する位置，大きさなどの情報 はロボットにはあらかじめ与えられていない。

\section{実匬 1: 完全回避発現行動}

完全回避発現行動の有効性を確かめるために, 静的障害物と してテーブルの上にペットボトルを置き，ロボットから見て障 害物の向こう側に目的位置を設定して実験を行った。この実験 結果を Fig. 6 に示す. 実線は, ロボットハンド手先の軌跡で あり，破線はロボットハンドの軌跡を $\mathrm{Z}=-1,000$ 平面に投影し た影である。なお，ロボットの有の位置が原点となっている。

ロボットハンドは, まず1）初期位置 A から目的位置 B 人直 線的に向かった。ここで, 2) 移動途中に障害物と接触し，その 接触を解除するように動作した。その後，3）接触のあった障 害物を回避するように動作し，続いて，4）その位置から目的 位置 Bに再度向かった．以降，障害物との接触が検知されるた びにこの動作を繰り返し $(5,6,7)$ 目的地に到達した。この 実験では，2 度同じ障害物に接触している，接触情報のみから 障害物の形状や位置を正確に特定するのは困難であるが, この ように繰り返し避けることで，うまく障害物を回避できること が確認できた。

\section{実医 2: 巻き付き回避行動}

巻き付き回避発現行動の有効性を確かめるために，ロボット 前方にペットボトルを置き， ロボットから見て障害物の奥側に 目的位置を設定して実験を行った。この実験結果を Fig. 7 に 示す.

ロボットハンドは，まず1）初期位置 A から目的位置 Bに向 かって直線的に移動した. 次に，2）で障害物とアームのショル タ位置に接触を検知したため, ショルタより手元の関節を固定 


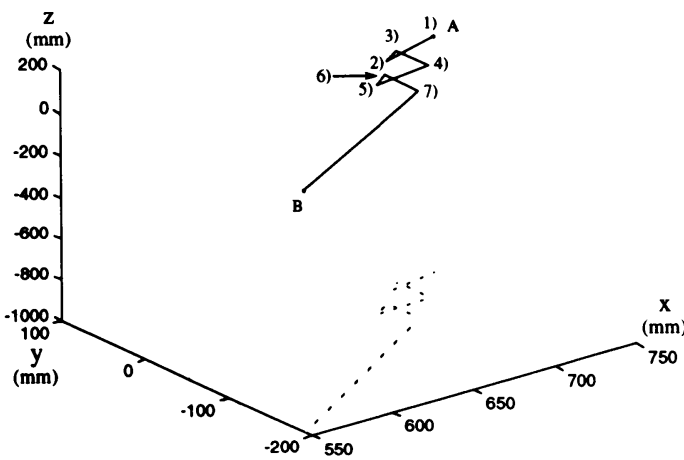

Fig. 6 Experimental results of completely avoiding EB

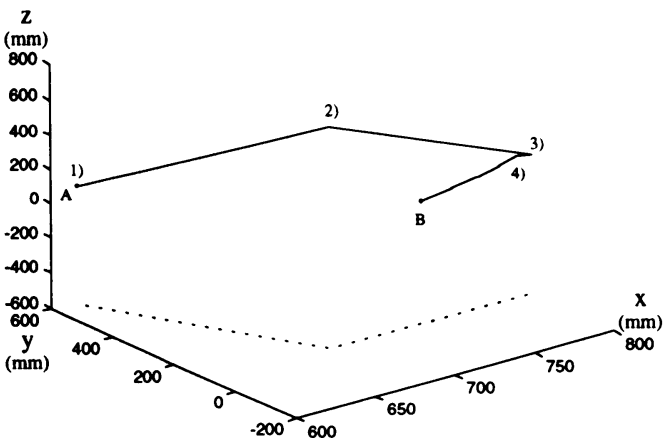

Fig. 7 Obstacle avoidance by using round and avoiding EB

し，ショルタより先方にある関節のみを用いてハンド先端を目 的位置に向かわせた．その後，動かすことのできる関節を曲げ て (3，4) 目的位置 B に到達した。

この発現行動は接触のあった関節より手元の関節を固定して 目的位置に向かうため, 自由度が極端に低下寸る。 そのため, 接触のあった場所や状況によっては, 目的位置に到達できない ことがある. しかしながら，本実験のように障害物のすぐ後ろ に目的位畺があるような場合には，非常に有効な回避行動で ある。

\section{実医 3：押し退け回避発現行動}

押し退け回避発現行動の有効性を確かめるために, ペットボ トルを 2 本を置き，ロボットから見て障害物の向こう側に目的 位置を設定して実験を行った。この実験結果を Fig. 8 に示す.

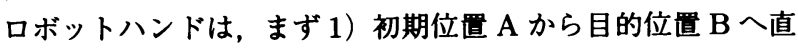
線的に向かった。ここで，2）移動途中に障害物を検知したた め，いったん停止しさらに少し押し込むことにより，障害物を 押せるかどうかを確認した。続いて，3）ロボットはアームを 左右に振り障害物を押した。 その後，4）接触が検知された位 置に戻り，目的位贯 Bに再度向かった，以降，障害物との接触 が検知されるたびにこの動作を絽り返し $(5 ， 6 ， 7)$ 目的位置 にBに到達した。

\section{实験 4: コップの運掓作業}

プランナが障害物回避のための発現行動を切り替えることに より，効率よく目的を達成できることを検証するために，障害 物のある環境でコップを運搬させる作業を行わせた．C 地点に コッブを置き，これを把持して目的位置 B まで運搬して置くタ

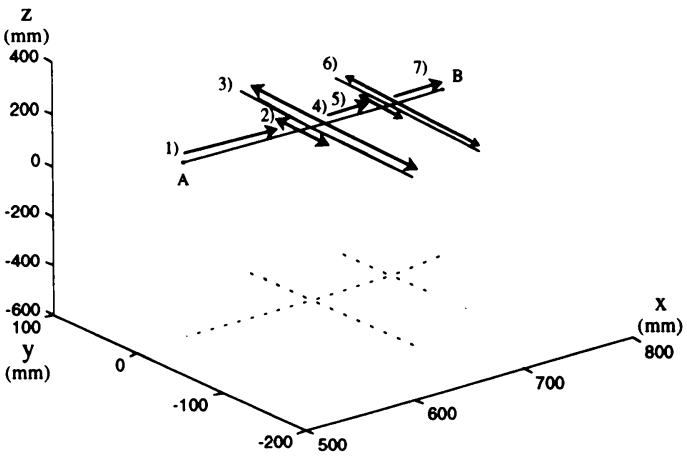

Fig. 8 Obstacle avoidance by using push and avoiding EB

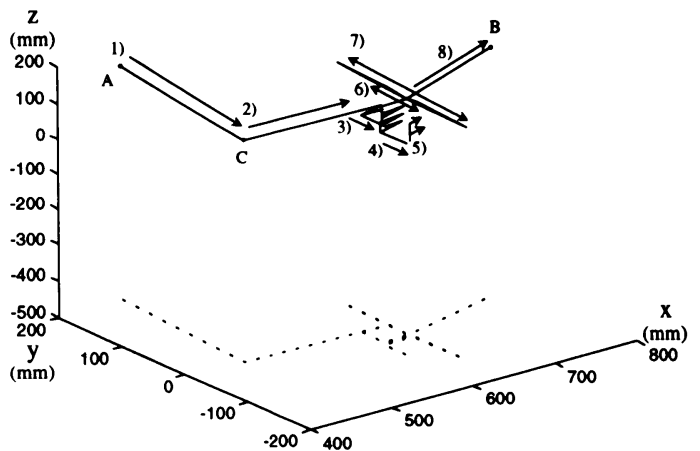

Fig. 9 Transportation of a cup by selecting multiple EBs

スクをプランナに与えた. 静的障害物としてペットボトル 2 本 をサブコール C と目的位置 $\mathrm{B}$ の間に置いた。この実験結果を Fig.9に示す.

ロボットはまず，まず 1）初期位置 A からサブゴールCに向 かい， C 地点でコップを把持した．続いて，2）目的位置 Bに 向かったが，3）ペットボトルに接触したため, 完全回避行動 が発現し，回避できる方向を搜した４４）で $\mathrm{y}$ 軸負の方向に障 害物を回避しようとした。しかしながら，さらに4）もう 1 本 のペットボトルに接触したため，5）回避の方向を変更し, 上 方に回避した．ところが，上方に避けてもすぐには回避するこ とはできなかった。この状況を監梘していたブランナが, 完全 回避発現行動から押し退け回避発現行動に切り替え，6）ペッ トボトルを左右に押し退けて目的位輻 Bに到達した。

本実験により，最初に設定した発現行動がうまく事態を解決 できていないときに，プランナが発現行動を切り替えることに より，効率よく目的を達成できることが確認できた。

実酸 5: 人間とのインタラクション

人間に危害を加えないことを確かめるために，移動中のアー ムの前方に人間の腕を差し出して停止させた．その結果, ペッ トボトルの場合と同様に，人間の腕をそれ以上押さないように， 完全回避行動により迁回できることが確認された．また，人間 の手を使って，動作中のアームロボットを押し続けた。その結 果，手を避けるようにアームをもと来た方向に下げることが確 認された。そして，さらに押し続けたところ、アームの稼做範 囲を超えたところで動作が停止することが確認された。 


\section{7. 考察}

以下に, Table 1 に揭げた要件について, 実験結果に基づい て考察を行う.

実験 5 により，EBBA に基づいて設計されたアームロボット システムが人間の腕を静的障害物として避け，さらに押し続け た場合でもそれを避け続け，人に危害を加えないように行動で きることが確認できた。この行動のためには，単に接触した場 合に衝突を回避する Reflective Avoidance 行動モジュールが利 用されており，接触状態が継続する間，この行動モジュールが 繰り返し起動し続けている。本研究では EBBA を用いたこと により，SSA に比べて用意する行動の数が少なくなっている 本システムでは各行動モジュールは単一 CPU 上の並行タスク として実装されている，そのため，本機能のようにサンプリン グ時間を短くしたタスクを実装するためには，全体の行動モ ジュールの数を少なくして実装できる EBBA が優位であると 考えられる.

また本システムでは，人がアームを押し続けると，アームが 腕を引き下げたにもかかわらず接触した状態が継続することか ら，プランナは動的な障害物が自分に向かって来ていると判断 し，発現行動を完全回避発現行動にしたまま避け続けることが できた。しかしながら，人の腕を静止させた場合，接触した物 体がペットボトルであるのか人であるのかを判断することはで きない.このような場合, 実験 4 のように押し退け回避発現行 動に切り替えるのことは不適切である. 本研究で用いた接触セ ンサのみでは，接触した対象が人であるのか物体であるのかを 判断することは不可能であるため, 今後, ビジョンシステムを 併用するなどして，人間に対しては押し退け回避を選択しない ようにするなどの工夫が必要である.

さらに本システムでは, ハンド先端部の動作速度を $10[\mathrm{~cm} / \mathrm{sec}]$ の低速に設定し, ウレタンスポンジで覆った接 触センサを全面に配置している，そのため，人間の腕を接触セ ンサにより検知してから避けても危害を加えることはないと考 えられる.しかしながら，ロボットに人間と同様の動作速度を 要求するとなると, 接触したと同時に危害を及はすことも考え られる．そのため動作速度を高速化するためには，ビジョンシ ステムを併用して人間が近付いた場合にのみ速度を変更できる ような工夫 $[10]$ が必要であると考えられる.動作速度の動的変 更に関しては, Move行動モジュールの速度パラメー夕を変更 することにより対応可能である.

次に, 静的ならびに動的障害物への対応について議論する. 静的障害物に関しては実験 $1 \sim 3$ により, 3 種類の回避方法それ ぞれにおいて，障害物を回避しながら目的を達成できることが 確認できた．また，動的な障害物に関しては，実験 1 3 3 の障 害物の存在がシステムにはあらかじめ与えられていないことか ら, 突如障害物が置かれた場合にも对応できていると考えられ

\footnotetext{
†本システムでは Table 6 に示した 3 種類の障害物回避方法を実装して いるが,これらの行動は level 0, 2, 3の三つの行動モジュール組み合 わせにより実現されている. SSA を用いた場合, level 0 の目的状態に 相当する行動モジュールを二つ, 同様に level 2 に三つ, level 3 に二 つの合計七つの行動モジュールを用意する必要がある。
}

る．さらに，移動する障害物に関しては，それが遠ざかる方向 に移動している場合には, 接触状態が回避されるため, 回避行 動がアクティベートされなくなり, Approaching 行動により目 的位置にハンド先端を接近させることが確認されている。一方, ハンドに向かって移動する場合には実験 5 により，接触状態を 回避するまで避け続けられることが確認された。

本システムは EBBA に基づいて設計したため, 3 種類の障害 物回避行動は三つの行動モジュールの目的状態の組み合わせと して実現されている。.これらの回避行動の設計では, 個々の行 動モジュールがとりうる排他的な行動をそれぞれ目的状態とし て設計し, 目的状態の組み合わせのうち, 意味のある回避行動 を選択することにより設計を行った. EBBAではこのように， ロボットが内在的に保持する機能（行動）をもとにして, 意味 のある発現行動を選択的に設計する枠組を与えていると考える ことができる．障害物回避のための行動の設計では，システム に内在する機能を最大限に引き出して，様々な行動パターンを 生成する必要があり， EBBA で提供している設計手法はこの設 計を容易なものにしていると考えることができる．本システム では接触センサのみを利用した障害物回避発現行動を設計した が，他のセンサを利用した場合でも，EBBA に基づく設計手法 は有効であると考えられる.

最後に, システムがフェイルしないことに関して議論する. 本実験と同様のことを一般のアームロボットを用いて行った場 合，ロボットは障害物に接触するとサーボエラーを引き起こし， 動作不能状態になるところである。本研究ではアーム全面に 接触センサを配したことにより，接触状態を確実に検知して， フェイルすることなく障害物回避が行えることが確認された。 さらに実験 4 により，プランナが 3 種類の回避行動を切り替え ながら，与えられたタスクを遂行できることが確認された。

システムがフェイルしないためには，上記のように複数通り の手段を効率よく切り替えられる必要がある. 本システムでは EBBAを用いたことにより，プランナは下位モジュールの動作 状態をそれらのモジュールの内部状態をセンサ入力として容易 に把握でき，それらの情報から発現させる行動を単純な判断機 構を用いて決定し，下位モジュールの目的状態を書き換えるだ けで回避行動を切り替えることが可能となっている。このよう に EBBAでは行動モジュールの状態の把握と制御を容易に行 うことのできる体組を提供できていると考えられる。

上記の議論で述べたように, EBBAを用いた設計では, シス テムが内在的に保持する機能をボトムアップに行動モジュール として積み上げ，内部状態ならびに目的状態を設定することに より行動モジュールの状態と制御を抽象化（abstraction）し， これらを再利用することにより様々な発現行動を設計するとい う観点からとらえると，オブジェクト指向的な設計方法 [11]を 提供していると考えることができる. 特に, 人間共存型ロボッ トの設計においてはリアクティブ性が重要であり, 場合によっ ては致命的な結果をもたらす可能性がある. そのため, 行動 モジュールの再利用による計算リソースの節約を可能とする EBBA の設計手法は，有効であると考えられる.

また EBBA に基づく制御システムは, プランナにより分割さ れたタスクを下位モジュールに指令するトップダウン的な制御 
と, 下位のリアクティブな行動モジュール群によるボトムアッ プ的な制御の両方を合わせ持った構造となっている。これらの インタフェースは, 内部状態ならびに目的状態の参照によって 行われており，それぞれのモジュールは非同期的に動作可能で ある、障害物回避などのリアクティブ性を要する行動は下位モ ジュール群により常時維持したまま, プランナは, 与えられた タスクを遂行することが可能となっている.

EBBA では行動モジュールのパラメータを変更することに より, システムの動作モードを動的に切り替える手法をとって いるが，これまでに類似のシステムがいくつか提案されてい る. P. Maes [12] は, 各行動モジュールが発火するための閾値 を設け,これらのパラメータを書き換えることによりシステム 全体が適応的にアクションを選択できるシステムを提案してい る. また J. Connell [13] は, ロボットをサーボレベル, SSA レベル, 記号処理レベルの 3 層からなるシステムとして SSS (Servo, Subsumption, Symbolic) アーキテクチャを提案して いる. しかしながら, 記号処理レベルから SSAレベルに対する 制御では行動モジュールの ON/OFF を行っているのみである. また,これらのシステムでは本研究のように, 行動モジュール のパラメータの書き換えによる発現行動の選択は行われてい ない.

\section{8. 結論}

本研究では, 人間共存型ロボットが具備すべき基本的な要件 ならびに機能についてまとめ，その機能を実現するための手法 として EBBA を提案した。 また, 障害物を確実に検知するこ とのできる接触センサを用いて, 双腕型自律ロボットの制御シ ステムを構築した. 実験により, 接触センサのみを利用したシ ステムとして，上記の要件を満足することが確認された．

我々は現在, EBBA を利用して CCD カメラを用いた視覚シ ステム, ならびに移動ロボットベースのナビゲーションシステ ム [2] を構築中である. 本システムと視覚システムを統合する
ことにより, 障害物接触時には確実に回避できる上で, さらに 視覚システムにより障害物を検知した場合には, 接触以前にそ れらを回避できるように, システムを発展させる計画である.

\section{参 考 文 献}

[1] 中内：“機械の知能と人間の知能一知能ロボットとヒューマンインタ フェース研究者の視点から一”, 日本機械学会第 74 期総会講演会, vol.5, pp.620-621, 1997.

[2] Y. Nakauchi and Y. Mori: Emergent Behavior Based Sensor Fusion for Robot Navigation System, Proc. of IEEE/SICE/RSJ Itnl. Conf. on Multisensor Fusion and Integration for Intelligent Systems, pp.525-532, 1996.

[3] D. Vischer: Cooperating Robot with Visual and Tactile Skills, IEEE Intl. Conf. on Robotics and Automation, pp.2018-2025, 1992.

[4] S.A. Stansfield: "Robotic Grasping of Unknown Objects: A Knowledge Based Approach," Intl. J. of Robotics Research, vol.10, no.4, pp.314-326, 1991.

[5] P.K. Allen et al.: "Autometed Tracking and Grasping of a Moving Object with a Robotic Hand-Eye System," IEEE Trans. on Robotics and Automation, vol.9, no.2, pp.152-165, 1993.

[6] R.A. Brooks, 五味: “複数の要素行動間の競合・協調により知能口 ボットの行動を決めるサプサンプションアーキテクチャ”, 日経イン テリジェントシステム別冊, 春号, pp.152-167, 1992.

[7] 久野：“ビヘービアベーストロボットの行動”, 日本ロボット学会誌, vol.11, no.8, pp.1178-1184, 1993.

[ 8 ] 西田, 中内, 森：“SSA を利用した自律移動型ロボットの開発”, 電 気学会産業計測制御研究会, IIC-95-56, pp.51-60, 1995.

[9] 西田, 中川, 中内, 森: “接触センサを用いた動的環境に適応したロボッ トの開発”, 日本機械学会論文集 C 編, vol.63, no.606, pp.172-178, 1997.

[10] S. Tadokoro et al.: A Human Recognition System for Avoidance of Robot Accidents, Proc. of IECON'91, pp.2247-2252, 1991.

[11] A. Goldberg and D. Robson: Smalltalk 80: The Language and its Implementation, Addison-Wesley, 1983.

[12] P. Maes: Adaptive Action Selection, Proc. of 13th Itnl. Conf. of the Cognitive Science Society, pp.108-113, 1991.

[13] J. Connell: SSS: A Hybrid Architecture Applied to Robot Navigation, Porc. of IEEE Itnl. Conf. on Robotics and Automation, pp.2719-2724, 1992.

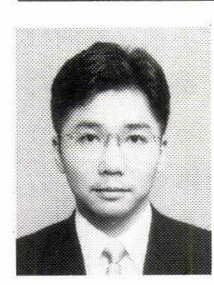

$\mathrm{ACM}$ 各会員.

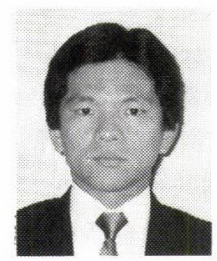

中内 靖 (Yasushi Nakauchi)

1963 年 10 月 23 日生. 1988 年慶應義塾大学電気 工学科卒業, 1993 年同大学院計算機科学専攻博士 課程修了. 工学博士. 同年防衛大学校機械工学教 室助手, 1994 年同大学校講師, 現在に至る.マル チエージェントインタフェース, 自律移動ロボット の研究に従事. 情報処理学会, 電子情報通信学会,

(日本ロボット学会正会員)

\section{森 泰親 (Yasuchika Mori)}

1952 年 5 月 21 日生. 1976 年早稲田大学電気工学 科卒業, 1981 年同大学院電気工学専攻博士課程修 了. 工学博士. (株) 東芝総合研究所, 埼玉大学工 学部助教授を経て, 1992 年より防衛大学校機械工 学教室助教授, 現在に至る. 制御系設計理論の研究 に従事, 1985 年計測自動制御学会論文賞受賞. 日 本機械学会, 計測自動制御学会, システム制御情報学会, IEEE 各会 員.

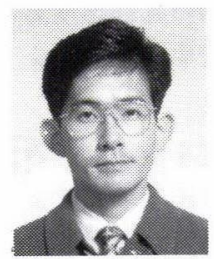

西田洋一郎 (Youichiro Nishida)

1967 年 10 月 16 日生. 1990 年防衛大学校機械工 学教室卒業, 現在同大学校研究科課程在学中. 自律 ロボットの研究に従事. 計測自動制御学会会員. 